\title{
Now Dew Disease Reports \\ First report of Lasiodiplodia theobromae causing canker on tapped Boswellia papyrifera trees in Ethiopia
}

\author{
Alemu Gezahgne ${ }^{1 *}$, Abraham Yirgu ${ }^{1}$ and Habtemaria Kassa ${ }^{2}$ \\ ${ }^{1}$ Forestry Research Center, P.O. Box 30708 Addis Ababa, Ethiopia; ${ }^{2}$ Center for International Forestry Research (CIFOR) \\ P.O. Box 5689, Addis Ababa Ethiopia
}

*E-mail: alexshig@yahoo.com

Received: 04 Jul 2013. Published: 24 Mar 2014. Keywords: Botryiodiplodia theobromae, gum exudates, frankincense production, tapping

Boswellia papyrifera (Burseraceae) is found mainly in the Amhara, Tigray and Benshangul Gumze Regions of Ethiopia (Vollesen, 1989). This economically important tree species is widely used for frankincense (incense) production. Incense is extracted by frequent, intensive and repeated wounding made at different directions and positions on the bole of the tree. Depending on the size of the tree, there could be between 6 and 16 tapping spots that are refreshed and widened 8-12 times each year at an interval of 15 to 20 days (Gebrehiwot, 2003). Tapping for incense has a negative impact on the survival rate, growth and reproduction of the tree (Rijkers et al., 2006) and wounding predisposes trees to microbial infection. Disease symptoms and death of Boswellia trees have been commonly observed in all areas where tapping has been practiced. Specific symptoms include canker formation, exudation of gum, wilting, dieback, vascular browning and death of the tree. This study was carried out to determine the cause of the observed disease on tapped Boswellia trees.

Samples were collected from Humera and Metema Districts, North Ethiopia. Isolation was made from ten tapped trees that developed scars and galls on the stem (Figs. 1, 2). No clear disease symptoms were observed in untapped trees. Pieces of wood pieces $\left(5 \mathrm{~mm}^{2}\right)$ were taken from each sampled tree, surface sterilised with $70 \%$ alcohol and inoculated on to malt extract agar (MEA) amended with streptomycin. Such pieces of wood were then incubated in a moist chamber at $25^{\circ} \mathrm{C}$ with $12 \mathrm{~h}$ light/dark cycle to induce fruiting structures. The pycnidia produced on the wood had a conical shape and were covered by dark grey mycelium. Spores collected from crushed pycnidia were transferred on to MEA. Pieces of mycelia from emerging fungal colonies were transferred to water agar medium containing sterilised pine needles and incubated at $25^{\circ} \mathrm{C}$ to produce spores for further morphological characterisation.

Colonies obtained from the different isolation procedures produced white and dense aerial mycelium, later turning black at the top and grey to black on the reverse side of the Petri dish. The brown coloured conidia were single septate, sub-ovoid to ellipsoid and longitudinally striated (Fig. 3) with dimensions of 19-30 x 12.5-15 $\mu \mathrm{m}$. These morphological characteristics were identical with the description of Lasiodiplodia theobromae (Pat.) Griffon \& Maubl (syn. Botryodiplodia theobromae), the anamorph of Botryosphaeria rhodina Berk \& Curt. Arx (Punithalingam, 1976).

A pathogenicity test was conducted in situ on the branches of ten randomly selected Boswellia trees. Two and three isolates of L. theobromae on MEA from Metema and Humera Districts respectively and pure MEA (control) were used. A $5 \mathrm{~mm}$ bark borer was used to make inoculation holes on the bark of B. papyrifera trees. Inoculated branches were covered with Parafilm to hold inoculum in place as well as to avoid desiccation and contamination of the inoculum. After three months, the size of the lesions developed on branches inoculated with $L$. theobromae measured between 14.3 and $15.7 \mathrm{~cm}$ (Fig. 4). No lesion developed on trees treated with the control. This test confirmed that $L$. theobromae is pathogenic to $B$. papyrifera trees in Ethiopia. $L$. theobromae has previously been reported to cause dieback and death of mango and cacao trees in Pakistan and Cameroon respectively (Khanzada et al., 2004; Mbenoun et al., 2008). This is the first report of $L$. theobromae infecting Boswellia papyrifera in Ethiopa, which represents a new constraint to the sustainable management of Boswellia papyrifera and incense production.

\section{Acknowledgements}

The authors would like to thank the Austrian Development Cooperation for financing this study through CIFOR Ethiopia, and the CIFOR for its logistical support.

\section{References}

Gebrehiwot K, 2003. Ecology and management of Boswellia papyrifera (Del.) Hochst. Dry forest in Tigray, Northern Ethiopia. Georg-AugustUniversity of Göttingen, Germany, $\mathrm{PhD}$ thesis.

Khanzada MA, Lodhi AM, Shahzad S, 2004. Mango dieback and gummosis in Sindh Pakistan caused by Lasiodiplodia theobromae. Plant Health Progress, 1094. http://www.plantmanagementnetwork.org/pup/php/d iagnosisguide/2004/mango/

Mbenoun M, Momo Zeusta EH, Samuels G, Nsouga Amougou F, Nyasse S, 2008. Dieback due to Lasiodiplodia theobromae, a new constraint to cocoa production in Cameroon. Plant Pathology 57, 381.

http://dx.doi.org/10.1111/j.1365-3059.2007.01755.x

Punithalingam E. 1976. Botryodiplodia theobromae. CMI Description of Pathogenic Fungi and Bacteria, No 519 Kew, Surrey, UK: Commonwealth Mycological Institute.

Rijkers T, Ogbazghi W, Wessel M, Bongers F, 2006. The effect of tapping for frankincense on sexual reproduction in Boswellia papyrifera. Journal of Applied Ecology 43, 1188-1195. http://dx.doi.org/10.1111/j.1365-2664.2006.01215.x

Vollesen, K, 1989. Burseraceae. In: Hedberg I, Edwards S, eds. Flora of Ethiopia, Volume 3, National Herbarium, Addis Ababa University and Uppsala University, 442-447.

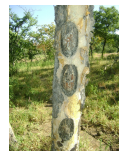

Figure 1

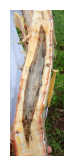

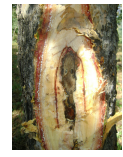

Figure 2

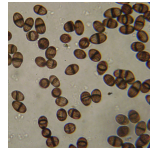

Figure 3

Figure 4

To cite this report: Gezahgne A, Yirgu A, Kassa H, 2014. First report of Lasiodiplodia theobromae causing canker on tapped Boswellia papyrifera trees in Ethiopia. New Disease Reports 29, 11. http://dx.doi.org/10.5197/j.2044-0588.2014.029.011

(c) 2014 The Authors

This report was published on-line at www.ndrs.org.uk where high quality versions of the figures can be found. 